\title{
Bifid Condylar Process: Cases Report
}

\author{
Proceso Condilar Bífido. Reporte de Casos \\ "Ramón Fuentes Fernández; **Homero Flores Flores; \\ **** Héctor Silva Mella \& *Tania Flores Lillo
}

\begin{abstract}
FUENTES, F. R.; FLORES, F. H.; SILVA, M. H.; \& FLORES, L. T. Bifid condylar process. Cases report. Int. J. Morphol., 27(2):539$541,2009$.

SUMMARY: The bifid condylar process is a rare anomaly. Most of the known cases are radiographic findings, mainly in ortopantomography and nuclear magnetic resonance. The condition is usually asymptomatic, while in some cases are associated with ankylosis of the temporomandibular joint. It is reported that the presence of bifid condylar process is not determined by age and gender, but the findings are among the ages of 3 to 67 years, with the average age of 35 years. The present report presents two cases of patients with abnormalities of condylar process detectable through radiographic examination.
\end{abstract}

KEY WORDS: Condylar process; Mandibular condyle; panoramic radiography; anatomic variation.

\section{INTRODUCTION}

The bifid condylar process is a rare developmental anomaly recently discussed in the literature (Gundlach $e t$ al., 1987). Hrdlicka (1941), first described this condition, reporting 21 cases (18 unilateral and 3 bilateral) in a series of skulls of the Smithsonian Institute. Schier (1948), made the first report of this anomaly in living persons. Acikgoz (2006) reported in their review of the literature only $42 \mathrm{ca}$ ses of living persons, of which 10 were bilateral. Oliveira de Sales et al. (2004) found 41 cases of this anomaly in his bibliography. Most of the known cases are radiographic findings in examinations such orthopantomography and magnetic resonance imaging. The condition is usually asymptomatic, while in some cases is associated with ankylosis of the temporomandibular joint (Shriki et al., 2005, De Moraes Ramos et al., 2006). It is reported that the presence of bifid condylar process is not determined by age or gender, but the findings are among the ages of 3 to 67 years, taking an average of 35 years of age (Antoniades et al., 2004). We performed an experimental model in pregnant rats which were injected teratogenic substances, such as $\mathrm{N}$ methyl-N-nitrosourea and form-hydroxamic acid from their results it was determined that the pathogenesis of bifid condylar process could be explained by the combination of a teratogenic agent with muscle insertions wrongly routed, resulting in the formation of a spinal bone (Gundlach et al.). Other causes for this change are: condylar fractures, developmental abnormalities, perinatal trauma and condylectomy surgery. Based on patterns of bifid condylar process it has been postulated that the anteroposterior pattern would result from a facial trauma during childhood and medial-lateral pattern could be related to the persistence of the fibrous septa of mandibular cartilage (Oliveira de Sales et al.). In the literature it is reported a case associated with the presence of alterations in jaw, face, fingers and nipples. The patient had a right bifid mandibular condyle and stretched, a left mandibular ramus short and thin, supernumerary nipples, supernumerary rudimentary sixth finger and clinodactyly of the $4^{\text {th }}$ and $5^{\text {th }}$ finger (Zohar \& Laurjan, 1987).

CASE I. Female patient aged 47 was treated in private practice in the city of Temuco, Chile. The patient was a rehabilitative treatment to replace missing teeth. Reviewing her panoramic radiography it was observed a compatible image with the bigemination of the left condylar process with mid lateral pattern. The patient had no facial asymmetry, history of trauma or signs that could be associated with the alteration. Her oral opening was $48 \mathrm{~mm}$ and left and right

\footnotetext{
* Departamento de Odontología Integral, Universidad de La Frontera, Chile.

** Facultad de Odontología Universidad de Concepción, Chile.

**** Departamento de Ciencias Básicas, Universidad de La Frontera, Chile.
} 
laterality of 10 and $11 \mathrm{~mm}$ respectively. The patient just recounted occasional discomfort in the left TMJ. After the rehabilitation it was prepared a left TMJ occlusal distraction appliance to use at night. (Figs. 1 and 2).

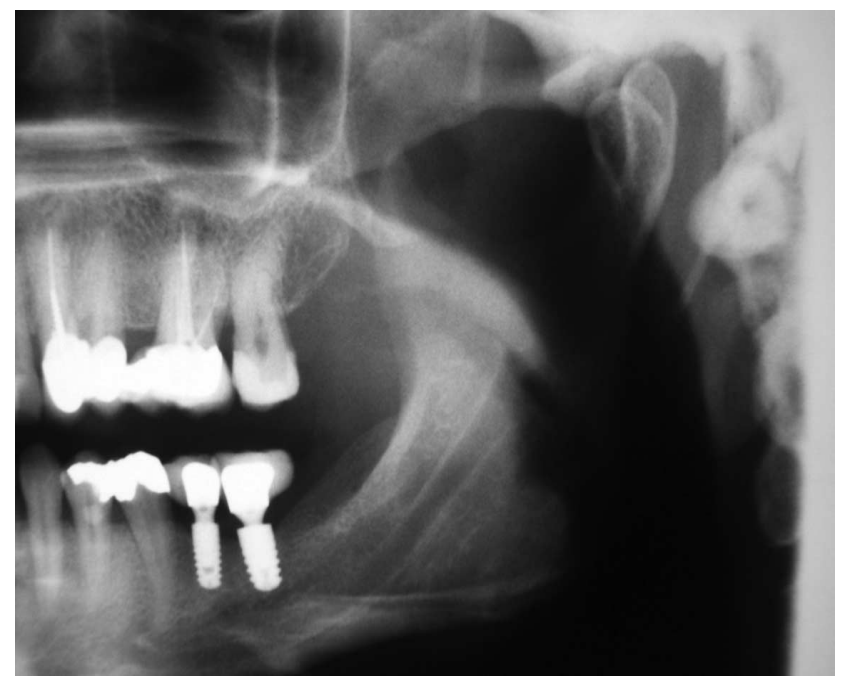

Fig 1. Panoramic radiograph revealed the anatomic variation of the left condylar process.

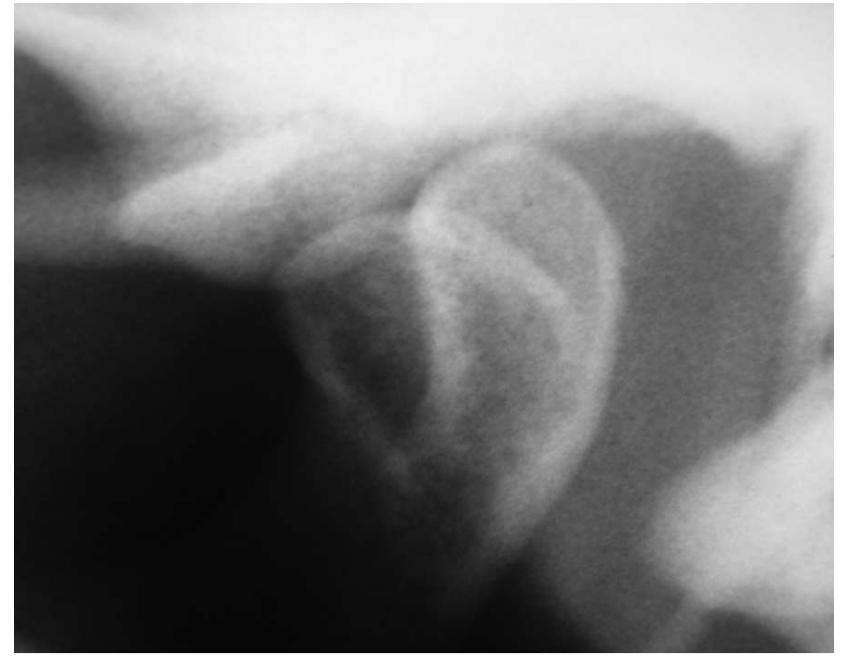

Fig. 2. Panoramic radiograph approach revealed the variation anatomic of the left condylar process.

CASE II. Six year old male patient was seen in private practice in the city of Concepción, he consults for a pain when eating and occasional right preauricular pain, this is the reason why it is requested a dated radiographic examination. At the clinical examination is determined AROM 26 mm; PROM 39 mm. Right click open, followed by articular blocking $2 / 5$ with right mandibular deflection and ipsilateral preauricular pain. When ordering more openness shows a mandibular accentuation, with intense and painful pop that allows maximum aperture at midline, with a second final crack. There is an open lock, painless dislocation, which is autoreduced with jaw movement, with pop and accentuation, which allows the closure in two times, with left and right deviation, with a new final click. Pain on palpation of the lateral and dorsal right TMJ. It is determined a surgical treatment and proceed to resection of the posterior segment of the condyle.

The post-surgical evaluation shows functional mandibular dynamics and painless with mutual right click deviation, and deviation in opening that ends in midline AROM: $38 \mathrm{~mm}$. (Figs. 3 and 4).

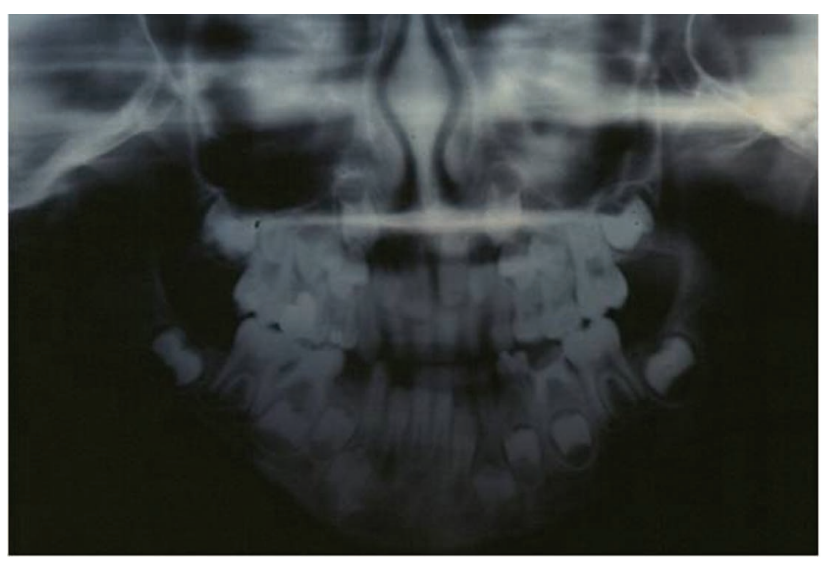

Fig 3.Panoramic radiograph revealed the anatomic variation of the right condylar process.

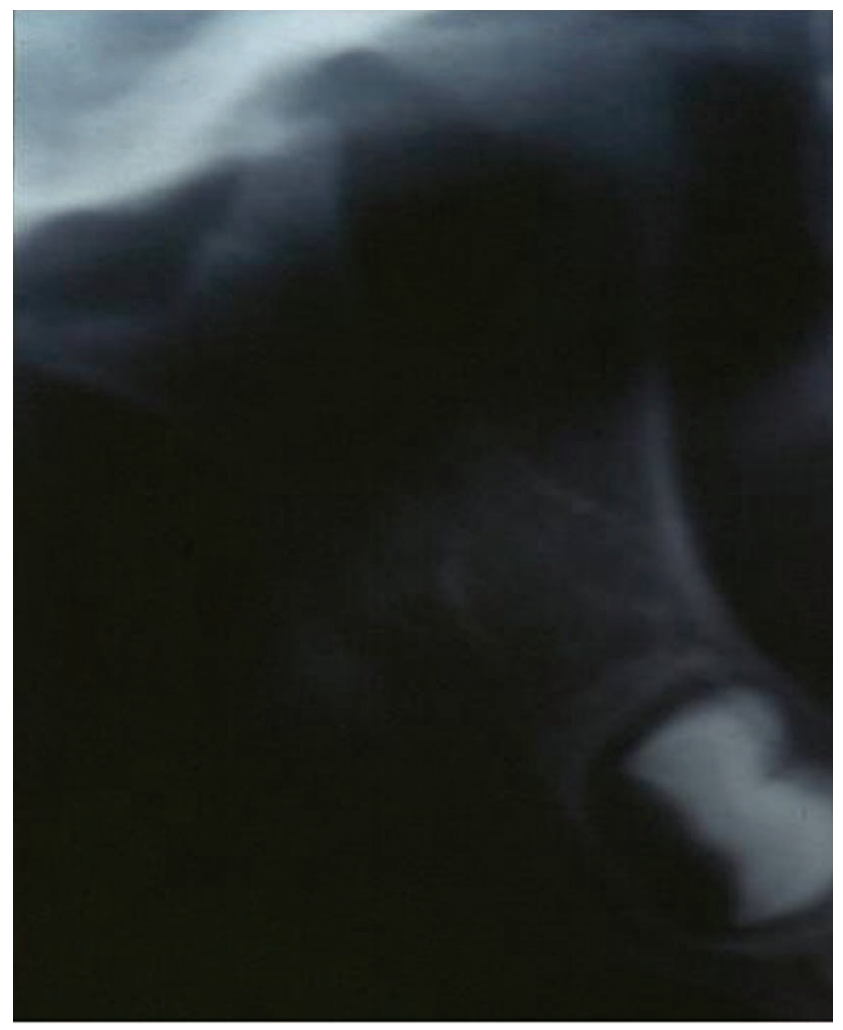

Fig 4.- TAC approach revealed the variation anatomic of the right condylar process (case 2). 
FUENTES, F. R.; FLORES, F. H.; SILVA, M. H. \& FLORES, L. T. Proceso condilar bífido. Relato de casos. Int. J. Morphol., 27(2):539-541, 2009.

RESUMEN: El cóndilo bífido es una anomalía poco común. La mayoría de los casos que se conocen son hallazgos radiográficos, principalmente en ortopantomografía y resonancia nuclear magnética. La condición es usualmente asintomática, mientras que en algunos casos se asocia con anquilosis de la articulación temporomandibular. Se reporta que la presencia de proceso condilar bífido no es determinada por edad ni género, sin embargo los hallazgos figuran entre las edades de 3 a 67 años, teniendo como promedio de edad los 35 años. En el presente reporte se presentan dos casos de pacientes con anomalía de forma del proceso condilar detectables a través de examen radiográfico.

PALABRAS CLAVE: Proceso condilar; Cóndilo mandibular; Radiografía panorámica; Variación anatómica.

\section{REFERENCES}

Acikgoz, A. Bilateral bifid mandibular condyle: case report. J. of oral rehabilitation., 33:784-7, 2006.

Antoniades, K.; Hadjpetrou, L.; Antoniades, V. \& Paraskevopoulos, K. Bilateral bifid condyle. Oral. surg. Oral med. Oral pathol. Oral radiol. endod., 97:535-8, 2004.

De Moraes, Ramos F. M.; De Vasconcelos, J.O.; Manzi, F.R.; Boscolo F.N. \& De Almeida, S.M. Bifid mandibular condyle : case report. J. of oral science., 48(1):35-7, 2006.

Gundlach, K.; Fuhrmann, A. \& Beckmann-Van der Ven, G. The Double -headed mandibular condyle. Oral. surg. Oral med. Oral pathol., 64:249-53, 1987.

Hrdlicka, A. Lower jaw: double condyles. Am. J. Phys. Anthop., 28:75-89, 1941.

Oliveira De Sales, M.A.; Do Amaral, J. I.; Batista De Amorim, R. F. \& De Almeida, R. Bifid mandibular condyle : case report and etiological considerations. Can. dent assoc., 70(3):158-62, 2004.

Schier, M. B. A. The temporal joint. A consideration of its probable functional and dysfunctional sequelae and report: condyle double head in living persons. Dent. Item interest., 70:1095-109, 1948.

Shriki, J.; Lev, R.; Wong, B.; Sundine, M. \& Hasso, A. Bifid mandibular condyle: $\mathrm{CT}$ and MR imaging appearance in two patients: case reports and review and the literature. Am. J. Neuroradiol., 26:1865-8, 2005.

Zohar, Y. \& Laurjan, N. Bifid condyle of the mandible with associated polythelia and manual anomalies. The $J$. of laryngologist and otology, 110:315-9, 1987.
Correspondence to:

Dr. Ramón Fuentes Femándes

Dpto. de Odontología Integral

Universidad de La Frontera

Manuel Montt 112

Temuco - CHILE.

e-mail: rfuentes@ufro.cl.

Received : 23-01-2009

Accepted: 04-13-2009 
